\title{
EVALUATION OF SOIL CORROSIVITY USING ELECTRICAL RESISTIVITY METHOD: A CASE STUDY OF PART OF THE UNIVERSITY OF JOS PERMANENT SITE.
}

\author{
DAKU S.S., DIYELMAK V.B., OTITOLAIYE O.A. and ABALAKA I.E. \\ Department of Geology, \\ Faculty of Natural Sciences, \\ University of Jos, Jos, Nigeria \\ DOI: $10.31364 / \mathrm{SCIRJ} / \mathrm{v} 7 . \mathrm{i} 3.2019 . P 0319623$ \\ http://dx.doi.org/10.31364/SCIRJ/v7.i3.2019.P0319623
}

\begin{abstract}
Soil resistivity could be influenced by soil moisture and concentrations of ionic soluble salts which is invariably regarded as the most comprehensive indicator of soil corrosivity. Soil corrosivity is a major concern, especially for buried infrastructure that is aging. Also, environmental protection policies now place emphasis on corrosion related issues. In view of this, the electrical resistivity of the soil of the study area were obtained to determine the corrosivity of the soil and its suitability for laying of pipes and other metals. The soil resistivity values were measured using the Wenner's electrode configuration method. The results showed that profile 1 has resistivity ranging from 60.64 to $707.00 \Omega \mathrm{m}$ which indicates a practically non-corrosive to slightly corrosive potential and composed of sandy-clay to clayey sand materials. However, profile 2 has a lower resistivity ranging from 13.13 to $95.36 \Omega$ indicating a moderately corrosive to slightly corrosive tendencies and could be clayey in composition. Profile 4 has resistivity values ranging from 8.55 to 199.16 $\Omega \mathrm{m}$ which reveals that the soil has a tendency to be either moderately, slightly, strongly or practically non-corrosive and this could be because of the presence of clay materials as well as nonuniformity in the composition of the soil types in this area. On the other hand, Profile 4 resistivity ranges from 15.35 to $127.31 \Omega \mathrm{m}$ which shows a moderately corrosive to slightly corrosive tendencies and characterized by clayey to sandy clay soils. The study area could be regarded as potentially noncorrosive, moderately corrosive and slightly corrosive.
\end{abstract}

Key words - Resistivity, Soil Corrosivity, Clay, Sandy-clay, Corrosity

\section{INTRODUCTION}

For soils, corrosivity may be defined in terms of soil's ability to corrode a material that may be buried in it. Idornigie [5] stressed the importance of mandatory testing of soil aggressiveness (corrosivity) before building foundations and pipes are laid or buried into the soil. The corrosivity of soil may depend on its mineralogical composition and/or its structure (Agunloye, [1]). Soil corrosive potential could be influenced by the geology of the area where the soil originates and/or anthropogenic activities.

Chemical analysis of soils alone is usually limited in determining the soluble constituents in water under standardized conditions. Therefore, only the base-forming elements, such as sodium, potassium, calcium, and magnesium as well as acidforming elements, such as carbonate, bicarbonate, chloride, nitrate, and sulfate are determined (Oyinkanola et al.[9]) . Oyubu [7] stated that based on experimental evidences, extremely high alkalinity lowers soil resistivity and increases soil corrosivity whereas mild alkalinity withstand corrosion for a long time. According to him, soils with pH of 5 (acidic) or below can lead to extreme corrosion rate and pitting of metallic objects. A neutral $\mathrm{pH}$ of about 7 is most desirable to minimize the potential for damage to earthing structures. Also, Olayinkanola et al. [9] reported that, fine-grained soils such as clays and some silts are considered to have a greater corrosion potential because they typically have lower hydraulic conductivity resulting from the accumulation of acid and base forming materials which cannot be leached out very quickly. However, they stated that granular soils such as sands and gravels are considered to have a reduced corrosion potential because of increased hydraulic conductivity resulting in the leaching of accumulated salts. They further suggested that, as a rule, soils with high moisture content, high electrical conductivity, low resistivity, high acidity, and high dissolved-salt content will be most corrosive (Alhazzaa, [2], Paillet $[8])$.

Moisture content has a profound effect on resistivity, so soils that are completely free of water have extremely high resistivity. Backfill materials will generally be more corrosive than native earth because the backfill soil has higher moisture content. In addition, backfill materials typically never reconsolidate back to the same degree as native soil, allowing more penetration and retention of water 
Therefore, this research seeks to evaluate the corrosion potential of soil around the permanent site of University of Jos using the electrical resistivity properties obtained from the area. Result from this study is expected to provide insight into the soils potentially corrosive areas around the measurement points at different depth levels.

\section{GEOLOGY AND PHYSIOGRAPHY OF THE STUDY AREA}

The geology of the area of study is shown in Figure 1.The aplo-pegmatitic granite gneiss predominates in the area. It is wide spread and occurred as crosscutting sheets with irregular shape.

The Neil's Valley granite porphyry which is part of the Younger Granite Ring Complexes that intruded into the basement. It occurs as massive pluton with relief as high as $1100 \mathrm{~m}$ above sea level, which is typical of the Younger Granites. It covers the northeastern section of the map of the study area. The rock forms Highlands and concentric intrusions typical of the Younger Granite Ring Complexes.

The Jos type biotite granite occupies the eastern and southeastern section of the map of the study area. The outcrop form large massif covering several hundred meters in size. The rock is mostly medium to coarse grained and have been affected by weathering along the joint planes thus breaking the rock into large boulders. The prominent hilly features in the study area are inselbergs and whalebacks which belong to the category of residual hills commonly associated with massive granite bodies (McCurry, [6]).

The area is drained by River Dilimi and its tributaries which cut across the basement areas in Barkin Rusau, Naraguta and Sabon Layi. The drainage is tectonically controlled as it is seen by its parallelism with the dominant N-S structures of the host rocks.

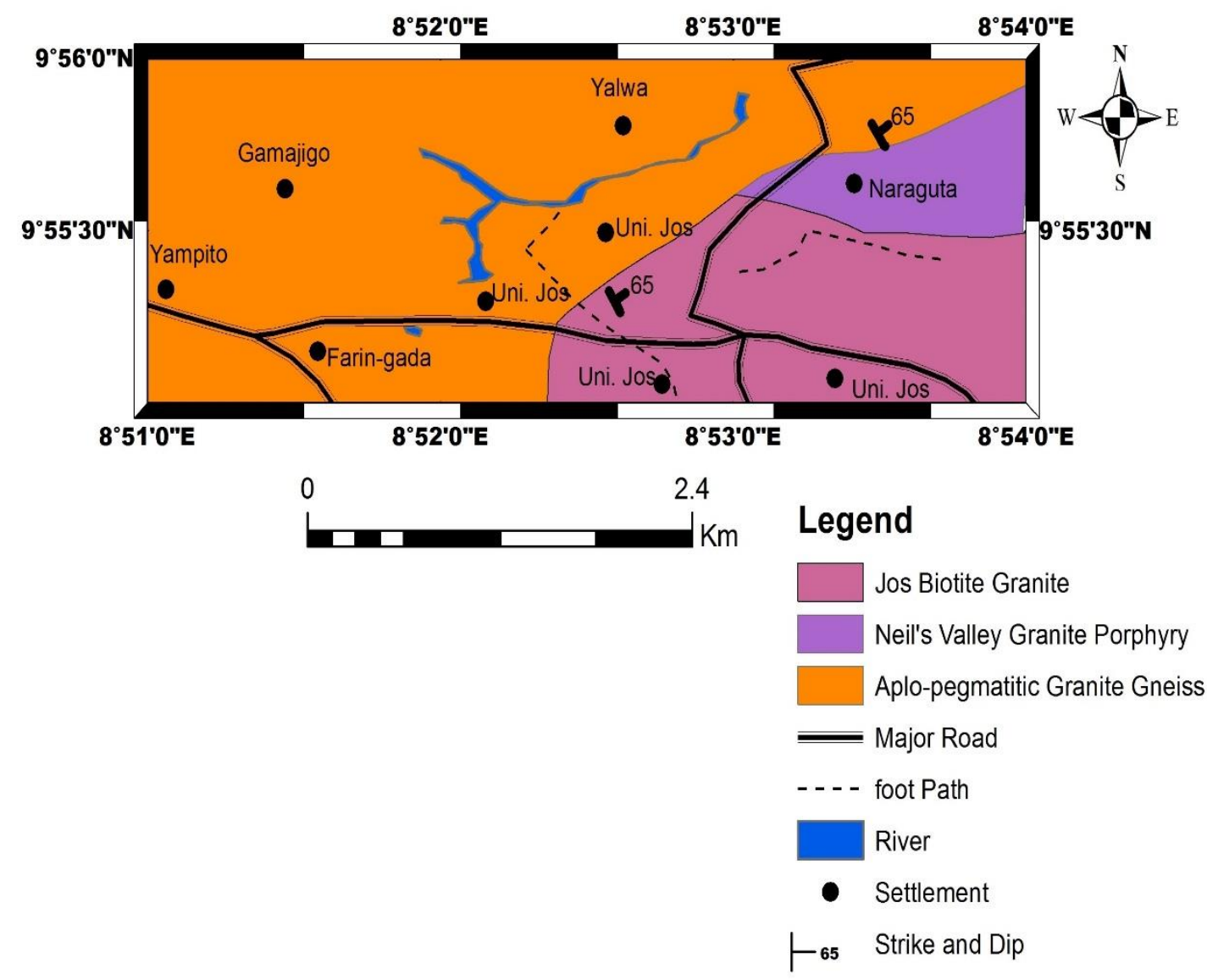

Figure 1: Geology of the study area.

III. METHOD OF STUDY 
The Wenner array method was used to determine the soil resistivity. This method utilizes two current electrodes from which current is passed into the ground and two potential electrodes which measures the potential difference between the two points. A total of 124 points were occupied from where four profiles were formed. For the resistivity to be effectively measured, the four electrodes were firmly inserted into the ground on a straight line and equally spaced (Fig. 2).

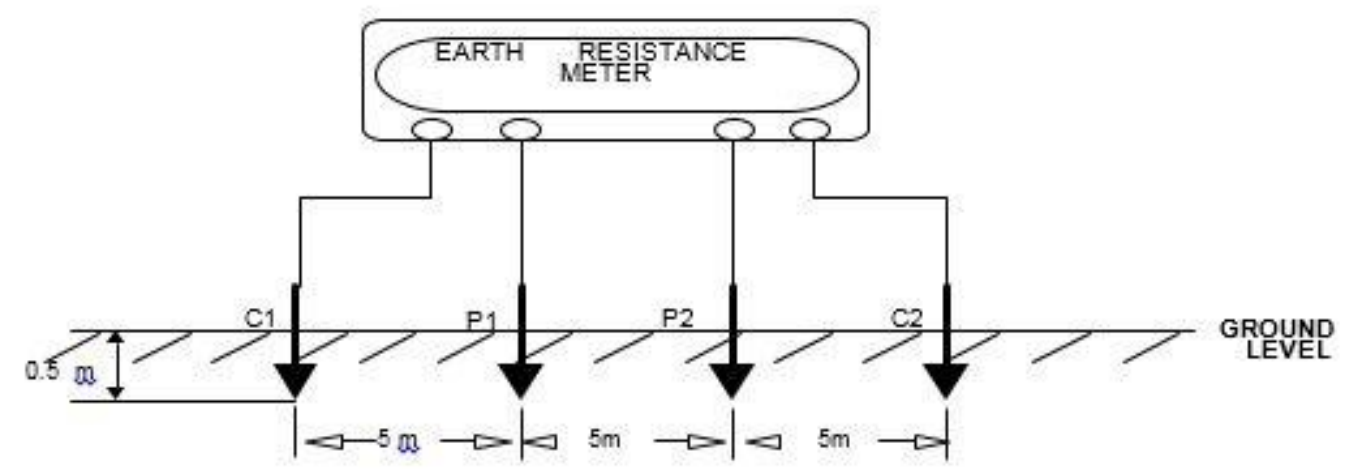

Fig. 2: A simple Wenner electrode configuration

The current electrodes are marked $\mathrm{C} 1$ and $\mathrm{C} 2$ while the potential electrodes are marked P1 and P2 and spaced at an equidistance of $5 \mathrm{~m}$ with a depth of penetration of $0.5 \mathrm{~m}$. The resistivity measurement were carried out by injecting current (I) through the two current electrodes $(\mathrm{C} 1$ and $\mathrm{C} 2)$ into the ground and recording the corresponding results of the potential difference (V) at the two electrodes (P1 and P2).

Ohm's law was then applied to calculate the apparent resistance: $\mathbf{R}=\mathbf{V} / \mathbf{I}$. However, in this case the resistivity meter used (Allied Omega ABEM SAS 4000 Terrameter) automatically generated the apparent resistivity.

\section{RESULTS AND DISCUSSION}

The resistivity values obtained were correlated with soil resistivity values as proposed by Baeckmann and Schenwenk, [3] and assessed based on their competence rating as proposed by Bayowa and Olayowola, [4].

Table 1: Soil Resistivity and its Corresponding Corrosivity based on Baeckmann and Schenwenk, [3]

\begin{tabular}{|l|l|}
\hline \multicolumn{1}{|c|}{ Soil resistivity $(\Omega \mathrm{m})$} & \multicolumn{1}{c|}{ Soil corrosivity } \\
\hline$<10$ & Very strongly corrosive (VSC) \\
\hline $10-60$ & Moderately corrosive (MC) \\
\hline $60-180$ & Slightly corrosive (SC) \\
\hline$>180$ & Practically non corrosive (PNC) \\
\hline
\end{tabular}

Table 2: Soil Competence Rating based on Bayowa and Olayiwola, [4].

\begin{tabular}{|c|c|c|}
\hline Apparent Resistivity $(\Omega \mathrm{m})$ & Lithology & Competence Rating \\
\hline$<100$ & Clay & Incompetent \\
\hline $100-350$ & Sandy clay & Moderately Competent \\
\hline $350-750$ & Clayey sand & Competent \\
\hline$>750$ & Sand/Laterite/Bedrock & Highly Competent \\
\hline
\end{tabular}

A. Profile One: Behind Chapel of Faith

This profile has a total of 21 stations with various values of resistivity. Table 3 and fig. 3 , indicate that the area generally has a high resistivity values with the highest value at station $14(706.996 \Omega \mathrm{m})$. However, station 15 has the lowest resistivity value of $60.6356 \Omega \mathrm{m}$. Therefore, based on Baeckmann and Schenwenk [3] and Bayowa and Olayiwola [4], the corrosivity rating of this area is Practically Non-corrosive and it is characteristically sandy-clay to clayey- sand materials which can be rated as 
moderately competent to competent strata while station 15 can be said to be Slightly Corrosive and composed of clay materials which is an incompetent material to construct on, based on the resistivity values given on Tables 1 and 2 .

Table 3: Summary of Resistivity Values and Corrosivity Rating of Profile 1

\begin{tabular}{|c|c|c|c|c|c|}
\hline $\mathrm{P} 1$ & NORTHINGS & EASTINGS & RESISTANCE & $2 \pi a R$ & CORROSIVITY \\
\hline 1 & 10.03333 & 9.003889 & 16.83 & 423.4428 & Practically non-corrosive \\
\hline 2 & 10.03250 & 9.003611 & 18.81 & 473.2596 & Practically non-corrosive \\
\hline 3 & 10.03167 & 9.003333 & 12.69 & 319.2804 & Practically non-corrosive \\
\hline 4 & 10.03111 & 9.003333 & 10.59 & 266.4444 & Practically non-corrosive \\
\hline 5 & 10.03056 & 8.991944 & 17.33 & 436.0228 & Practically non-corrosive \\
\hline 6 & 10.03000 & 9.002778 & 12.66 & 318.5256 & Practically non-corrosive \\
\hline 7 & 10.02917 & 9.002778 & 9.50 & 239.0200 & Practically non-corrosive \\
\hline 8 & 10.02833 & 9.002778 & 15.97 & 401.8052 & Practically non-corrosive \\
\hline 9 & 10.02778 & 9.002500 & 16.54 & 416.1464 & Practically non-corrosive \\
\hline 10 & 10.02694 & 9.001944 & 19.57 & 492.3812 & Practically non-corrosive \\
\hline 11 & 10.02614 & 9.001667 & 12.17 & 306.1972 & Practically non-corrosive \\
\hline 12 & 10.02556 & 9.001111 & 19.32 & 486.0912 & Practically non-corrosive \\
\hline 13 & 10.02472 & 9.000833 & 22.80 & 573.6480 & Practically non-corrosive \\
\hline 14 & 10.02389 & 9.000278 & 28.10 & 706.9960 & Practically non-corrosive \\
\hline 15 & 10.02333 & 9.000000 & 2.41 & 60.6356 & Slightly corrosive \\
\hline 16 & 10.0225 & 8.999722 & 22.80 & 573.648 & Practically non-corrosive \\
\hline 17 & 10.03333 & 8.999444 & 15.64 & 393.5024 & Practically non-corrosive \\
\hline 18 & 10.0325 & 8.999167 & 9.59 & 241.2844 & Practically non-corrosive \\
\hline 19 & 10.03167 & 8.999167 & 8.34 & 209.8344 & Practically non-corrosive \\
\hline 20 & 10.03111 & 8.998889 & 9.28 & 233.4848 & Practically non-corrosive \\
\hline 21 & 10.03056 & 8.999167 & 7.37 & 185.4292 & Practically non-corrosive \\
\hline
\end{tabular}




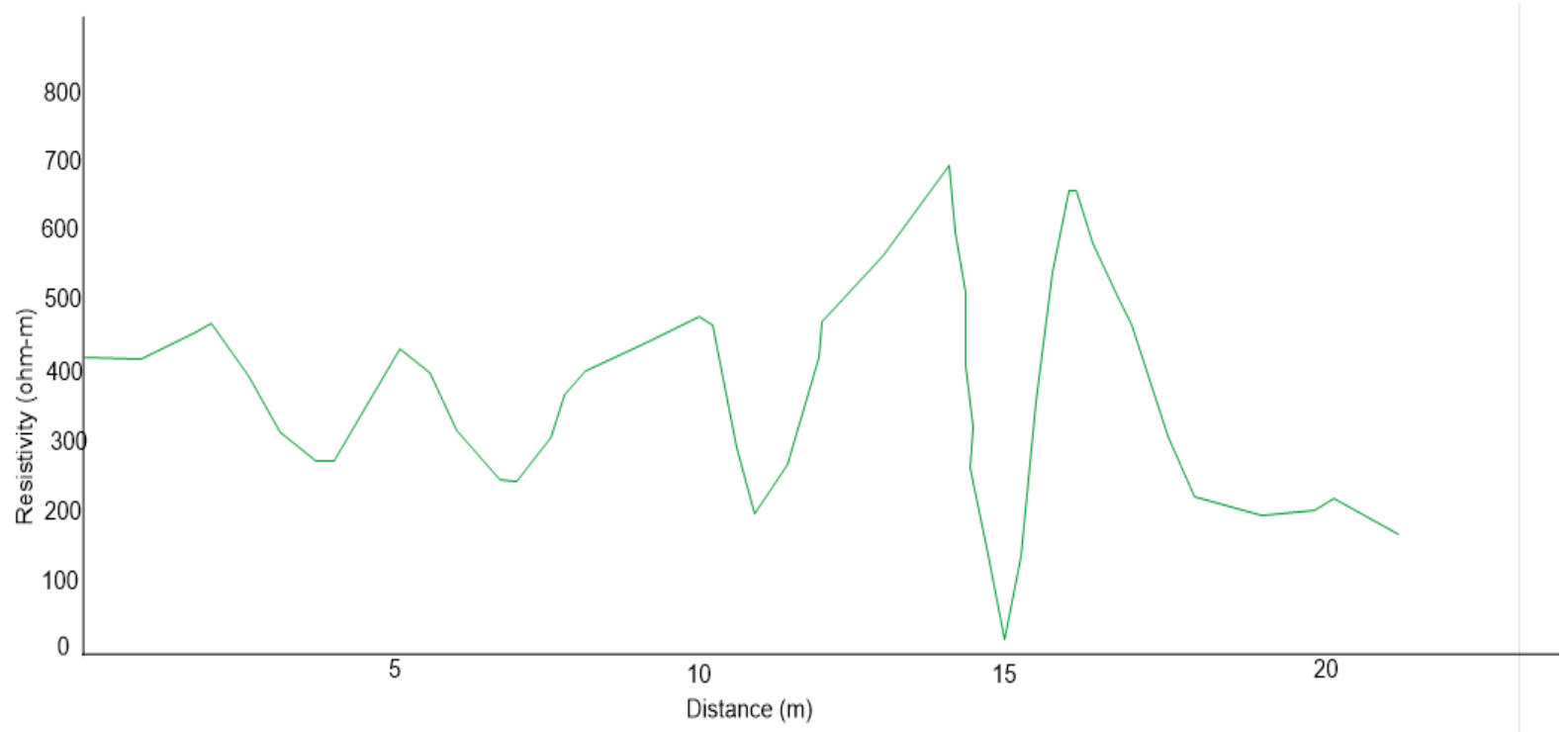

Fig. 3: Graph of Resistivity against Distance showing the Corrosivity of Profile 1 in the study area.

\section{B. Profile Two: Naraguta Hostels}

This profile has a total of 33 stations showing variations in the resistivity values. The resistivity Values of this profile generally ranges from low to intermediate as shown in Table 4 and plotted in Fig. 4 . The highest resistivity value of $95.3564 \Omega \mathrm{m}$ was recorded at station 1 and the lowest resistivity value of $13.13352 \Omega \mathrm{m}$ was recorded at station 29 .

Also, the resistivity values obtained from this survey was compared with the standard proposed by Baeckmann and Schenwenk [3]. The result indicates that the profile is generally Moderately Corrosive with only six stations representing about 18 percent of the profile is said to be Slightly Corrosive. Therefore, from the resistivity values obtained in the profile, it can be suggested that the profile is generally made up of clayey soil. Hence, its ability to retain water within its pore spaces and also lower the resistivity of the soil.

Table 4: Summary of Resistivity Values and Corrosivity Rating of Profile 2

\begin{tabular}{|c|c|c|c|c|c|}
\hline P2 & NORTHINGS & EASTINGS & RESISTANCE & $2 \pi a R$ & CORROSIVITY \\
\hline 1 & 10.11056 & 8.956111 & 3.79 & 95.3564 & Slightly corrosive \\
\hline 2 & 10.12889 & 8.956389 & 2.88 & 72.4608 & Slightly corrosive \\
\hline 3 & 10.12778 & 8.956667 & 1.93 & 48.5588 & Moderately corrosive \\
\hline 4 & 10.12917 & 8.956944 & 1.98 & 49.8168 & Moderately corrosive \\
\hline 5 & 9.966944 & 8.957222 & 3.27 & 82.2732 & Slightly corrosive \\
\hline 6 & 9.966944 & 8.957500 & 2.72 & 68.4352 & Slightly corrosive \\
\hline 7 & 9.970278 & 8.958056 & 1.94 & 48.8104 & Moderately corrosive \\
\hline 8 & 9.971667 & 8.958056 & 2.31 & 58.1196 & Moderately corrosive \\
\hline 9 & 9.973333 & 8.958056 & 1.02 & 25.6632 & Moderately corrosive \\
\hline 10 & 9.975000 & 8.958611 & 1.19 & 29.9404 & Moderately corrosive \\
\hline 11 & 9.976667 & 8.958889 & 1.21 & 30.4436 & Moderately corrosive \\
\hline 12 & 9.978056 & 8.959444 & 0.89 & 22.3924 & Moderately corrosive \\
\hline 13 & 9.982222 & 8.962500 & 2.84 & 71.4544 & Slightly corrosive \\
\hline 14 & 9.983889 & 8.963056 & 0.65 & 16.3540 & Moderately corrosive \\
\hline 15 & 9.985556 & 8.963333 & 1.25 & 31.4500 & Moderately Corrosive \\
\hline 16 & 9.987222 & 8.963889 & 0.81 & 20.4551 & Moderately corrosive \\
\hline 17 & 9.988889 & 8.964167 & 1.51 & 37.9916 & Moderately Corrosive \\
\hline
\end{tabular}




\begin{tabular}{|l|l|l|l|l|l|}
\hline 18 & 9.990278 & 8.964444 & 1.26 & 31.7016 & Moderately Corrosive \\
\hline 19 & 9.991944 & 8.964444 & 1.39 & 34.9724 & Moderately Corrosive \\
\hline 20 & 9.993611 & 8.965000 & 1.25 & 31.4500 & Moderately Corrosive \\
\hline 21 & 9.995000 & 8.965556 & 0.99 & 24.9084 & Moderately Corrosive \\
\hline 22 & 9.996667 & 8.965556 & 1.81 & 45.5396 & Moderately Corrosive \\
\hline 23 & 9.998611 & 8.964444 & 1.26 & 31.7016 & Moderately Corrosive \\
\hline 24 & 10.00028 & 8.964722 & 1.48 & 37.2368 & Moderately Corrosive \\
\hline 25 & 10.00194 & 8.965000 & 1.23 & 30.9468 & Moderately Corrosive \\
\hline 26 & 10.00333 & 8.964722 & 1.90 & 47.8040 & Moderately Corrosive \\
\hline 27 & 9.999722 & 8.964722 & 2.38 & 59.8808 & Moderately Corrosive \\
\hline 28 & 10.00694 & 8.964722 & 2.79 & 70.1964 & Slightly Corrosive \\
\hline 29 & 10.00833 & 8.965000 & 0.522 & 13.13352 & Moderately Corrosive \\
\hline 30 & 10.01000 & 8.965000 & 0.91 & 22.97108 & Moderately Corrosive \\
\hline 31 & 10.01167 & 8.965278 & 1.32 & 33.2112 & Moderately Corrosive \\
\hline 32 & 10.01361 & 8.965833 & 1.12 & 28.1792 & Moderately Corrosive \\
\hline 33 & 10.01500 & 9.166111 & 2.06 & 51.8296 & Moderately Corrosive \\
\hline
\end{tabular}

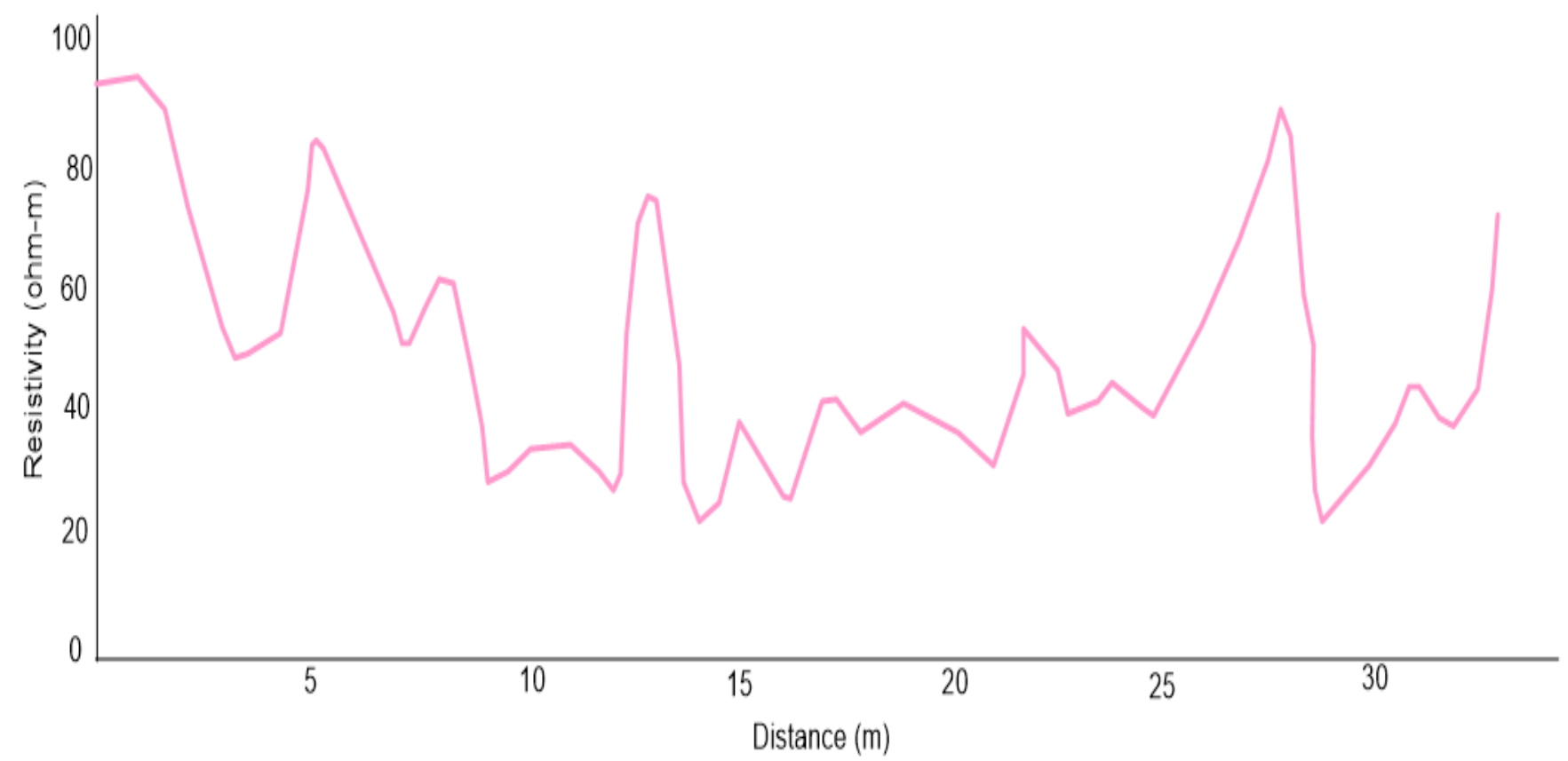

Fig. 4: Graph of Resistivity against Distance showing the Corrosivity of Profile 2 in the study area.

\section{Profile Three: Department of Geology}

This profile has a total of 32 stations with various resistivity values. From the resistivity values in Table 5 and Fig. 5 , the area shows low, intermediate and high resistivity values with the highest value at station $29(199.0156 \Omega \mathrm{m})$ and the lowest resistivity value of $8.5544 \Omega \mathrm{m}$ at station 32. Therefore, comparing this result with Table 1, it can be deduced that the profile is predominantly slightly corrosive representing $66 \%$ of the profile while nine (9) of the stations are moderately corrosive which makes up 28 percent of the profile. In this profile, stations 19 and 29 have resistivity values greater than $180 \Omega \mathrm{m}$ (Table 5) and hence indicate that the stations are practically non-corrosive. Also, station 32 has a resistivity value less than $100 \Omega \mathrm{m}$ (Table 5) 
indicating that the station is very strongly corrosive which could be due to the presence of clay materials around the station. Perhaps, the non-uniformity of soil types within the study area could be responsible for the variation in resistivity values in this station.

Table 5: Summary of Resistivity Values and Corrosivity Rating of Profile 3

\begin{tabular}{|c|c|c|c|c|c|}
\hline P3 & NORTHINGS & EASTINGS & RESISTANCE & $2 \pi a R$ & CORROSIVITY \\
\hline 1 & 10.08028 & 8.911944 & 2.99 & 75.228 & Slightly Corrosive \\
\hline 2 & 10.08056 & 8.910833 & 4.25 & 106.930 & Slightly Corrosive \\
\hline 3 & 10.08083 & 8.909722 & 4.05 & 101.898 & Slightly Corrosive \\
\hline 4 & 10.08083 & 8.908333 & 3.71 & 93.3436 & Slightly Corrosive \\
\hline 5 & 10.08083 & 8.907500 & 6.61 & 166.308 & Slightly Corrosive \\
\hline 6 & 10.08056 & 8.907500 & 5.60 & 140.896 & Slightly Corrosive \\
\hline 7 & 10.08056 & 8.905278 & 3.63 & 91.331 & Slightly Corrosive \\
\hline 8 & 10.08056 & 8.903889 & 3.41 & 85.796 & Slightly Corrosive \\
\hline 9 & 10.08056 & 8.903056 & 1.26 & 31.702 & Moderately Corrosive \\
\hline 10 & 10.08083 & 8.901944 & 2.97 & 74.725 & Slightly Corrosive \\
\hline 11 & 10.08167 & 8.900833 & 2.04 & 51.326 & Moderately Corrosive \\
\hline 12 & 10.08278 & 8.900556 & 2.03 & 51.075 & Moderately Corrosive \\
\hline 13 & 10.08333 & 8.899444 & 1.32 & 33.211 & Moderately Corrosive \\
\hline 14 & 10.08389 & 8.898333 & 1.41 & 35.476 & Moderately Corrosive \\
\hline 15 & 10.08417 & 8.897500 & 1.07 & 26.921 & Moderately Corrosive \\
\hline 16 & 10.08472 & 8.896389 & 2.52 & 63.403 & Slightly Corrosive \\
\hline 17 & 10.08528 & 8.895278 & 1.25 & 31.450 & Moderately Corrosive \\
\hline 18 & 10.08556 & 8.894167 & 3.18 & 80.009 & Slightly Corrosive \\
\hline 19 & 10.08639 & 8.893333 & 7.80 & 196.248 & Practically non-Corrosive \\
\hline 20 & 10.08694 & 8.892222 & 7.11 & 178.888 & Slightly Corrosive \\
\hline 21 & 10.08722 & 8.891111 & 2.24 & 56.358 & Moderately Corrosive \\
\hline 22 & 10.08778 & 8.89000 & 2.45 & 61.642 & Slightly Corrosive \\
\hline 23 & 10.08833 & 8.888889 & 4.56 & 114.730 & Slightly Corrosive \\
\hline 24 & 10.08917 & 8.888056 & 5.12 & 128.819 & Slightly Corrosive \\
\hline 25 & 10.08944 & 8.886944 & 5.44 & 136.870 & Slightly Corrosive \\
\hline 26 & 10.09000 & 8.885833 & 5.56 & 139.890 & Slightly Corrosive \\
\hline 27 & 10.09083 & 8.885000 & 5.43 & 136.619 & Slightly Corrosive \\
\hline 28 & 10.09111 & 8.884167 & 7.30 & 183.668 & Slightly Corrosive \\
\hline 29 & 10.09167 & 9.049444 & 7.91 & 199.016 & Practically non-Corrosive \\
\hline 30 & 10.09222 & 9.048333 & 4.91 & 123.536 & Slightly Corrosive \\
\hline 31 & 10.09250 & 9.047500 & 1.02 & 25.6632 & Moderately Corrosive \\
\hline 32 & 10.03750 & 9.046111 & 0.34 & 8.554 & Very strongly Corrosive \\
\hline
\end{tabular}




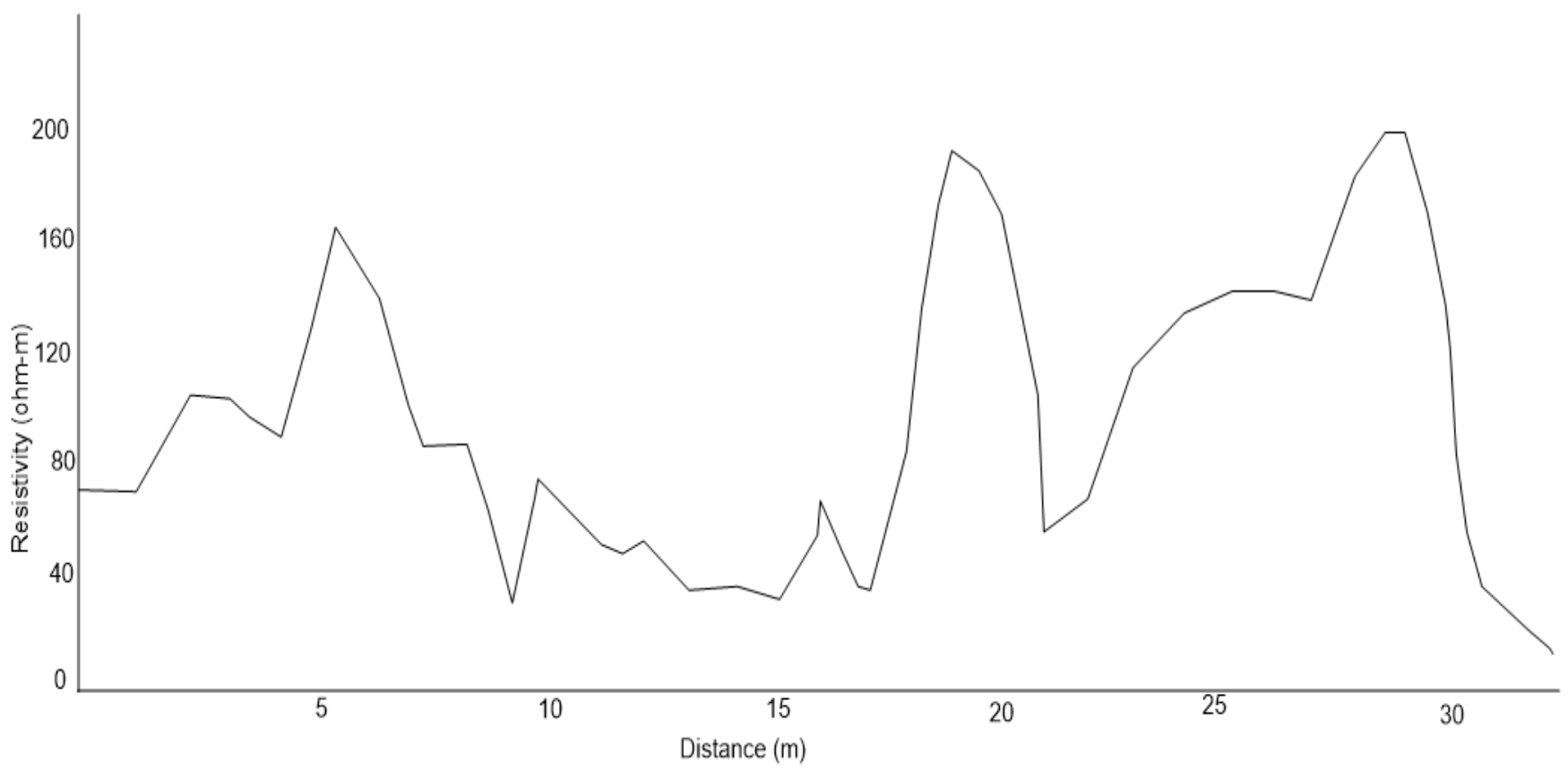

Fig. 5: Graph of Resistivity against Distance showing the Corrosivity of Profile 3 in the study area.

\section{Profile Four: Faculty of Arts}

This profile has 38 stations showing significant variation in the resistivity values obtained and this ranges from low to intermediate (Table 6 and Fig. 6), with the highest resistivity value of $127.3096 \Omega \mathrm{m}$ at station 1 and the lowest resistivity value of $15.3476 \Omega \mathrm{m}$ at station 34 . In relation to Table 1 , the corrosivity of the area ranges from moderately corrosive to slightly corrosive. The resistivity values also indicate that the soil in this profile could be clayey to sandy clay soil (Table 2).

Table 6: Summary of Resistivity Values and Corrosivity Rating of Profile 4

\begin{tabular}{|l|c|c|c|r|l|}
\hline P4 & NORTHINGS & EASTINGS & \multicolumn{1}{|c|}{ RESISTANCE } & \multicolumn{1}{|l|}{$2 \pi a R$} & CORROSIVITY \\
\hline 1 & 10.08861 & 8.891944 & 5.06 & 127.3096 & Slightly Corrosive \\
\hline 2 & 10.08972 & 8.892222 & 4.45 & 111.9620 & Slightly Corrosive \\
\hline 3 & 10.09111 & 8.892778 & 2.96 & 74.4736 & Slightly Corrosive \\
\hline 4 & 10.09194 & 8.893056 & 2.92 & 73.4672 & Slightly Corrosive \\
\hline 5 & 10.09333 & 8.893611 & 4.42 & 111.2072 & Slightly Corrosive \\
\hline 6 & 10.09444 & 8.893889 & 4.56 & 114.7296 & Slightly Corrosive \\
\hline 7 & 10.09528 & 8.894167 & 4.22 & 106.1752 & Slightly Corrosive \\
\hline 8 & 10.09667 & 8.894722 & 2.55 & 64.1580 & Slightly Corrosive \\
\hline 9 & 10.0975 & 8.894722 & 2.51 & 63.1516 & Slightly Corrosive \\
\hline 10 & 10.09889 & 8.895000 & 2.39 & 60.1324 & Slightly Corrosive \\
\hline 11 & 10.09972 & 8.895556 & 1.74 & 43.7784 & Moderately Corrosive \\
\hline 12 & 10.10111 & 8.895278 & 2.16 & 54.3456 & Moderately Corrosive \\
\hline 13 & 10.10222 & 8.895278 & 3.37 & 84.7892 & Slightly Corrosive \\
\hline 14 & 10.10417 & 8.895000 & 3.49 & 87.8084 & Slightly Corrosive \\
\hline 15 & 10.10444 & 8.894444 & 2.51 & 63.1516 & Slightly Corrosive \\
\hline 16 & 10.10528 & 8.894722 & 1.86 & 46.7976 & Moderately Corrosive \\
\hline 17 & 10.10667 & 8.894444 & 1.10 & 27.6760 & Moderately Corrosive \\
\hline 18 & 10.1075 & 8.893889 & 1.64 & 41.2624 & Moderately Corrosive \\
\hline 19 & 10.10889 & 8.895000 & 2.68 & 67.4288 & Slightly Corrosive \\
\hline 20 & 10.11000 & 8.895000 & 3.42 & 86.0472 & Slightly Corrosive \\
\hline 21 & 10.11139 & 8.895278 & 3.09 & 77.7444 & Slightly Corrosive \\
\hline
\end{tabular}




\begin{tabular}{|l|l|l|l|l|l|}
\hline 22 & 10.11222 & 8.895000 & 1.57 & 39.5012 & Moderately Corrosive \\
\hline 23 & 10.11361 & 8.895278 & 2.45 & 61.6420 & Slightly Corrosive \\
\hline 24 & 10.11444 & 8.895278 & 2.56 & 64.4096 & Slightly Corrosive \\
\hline 25 & 10.11583 & 8.895556 & 2.22 & 55.8552 & Moderately Corrosive \\
\hline 26 & 9.966944 & 8.895278 & 1.71 & 43.0236 & Moderately Corrosive \\
\hline 27 & 9.968056 & 8.895833 & 3.07 & 77.2412 & Slightly Corrosive \\
\hline 28 & 9.968889 & 8.896389 & 2.66 & 66.9256 & Slightly Corrosive \\
\hline 29 & 9.970000 & 8.897500 & 1.89 & 47.5524 & Moderately Corrosive \\
\hline 30 & 9.971111 & 8.896944 & 2.71 & 68.1836 & Slightly Corrosive \\
\hline 31 & 9.972500 & 8.897222 & 2.10 & 52.8360 & Moderately Corrosive \\
\hline 32 & 9.973611 & 8.897222 & 1.30 & 32.7080 & Moderately Corrosive \\
\hline 33 & 9.974444 & 9.097500 & 1.31 & 32.9596 & Moderately Corrosive \\
\hline 34 & 9.975833 & 9.097500 & 0.61 & 15.3476 & Moderately Corrosive \\
\hline 35 & 9.976944 & 9.0980560 & 0.97 & 24.4052 & Moderately Corrosive \\
\hline 36 & 9.977778 & 9.0980560 & 0.69 & 17.3604 & Moderately Corrosive \\
\hline 37 & 9.978889 & 9.0822220 & 0.60 & 15.0960 & Moderately Corrosive \\
\hline 38 & 9.980000 & 9.0991670 & 0.78 & 19.6248 & Moderately Corrosive \\
\hline
\end{tabular}

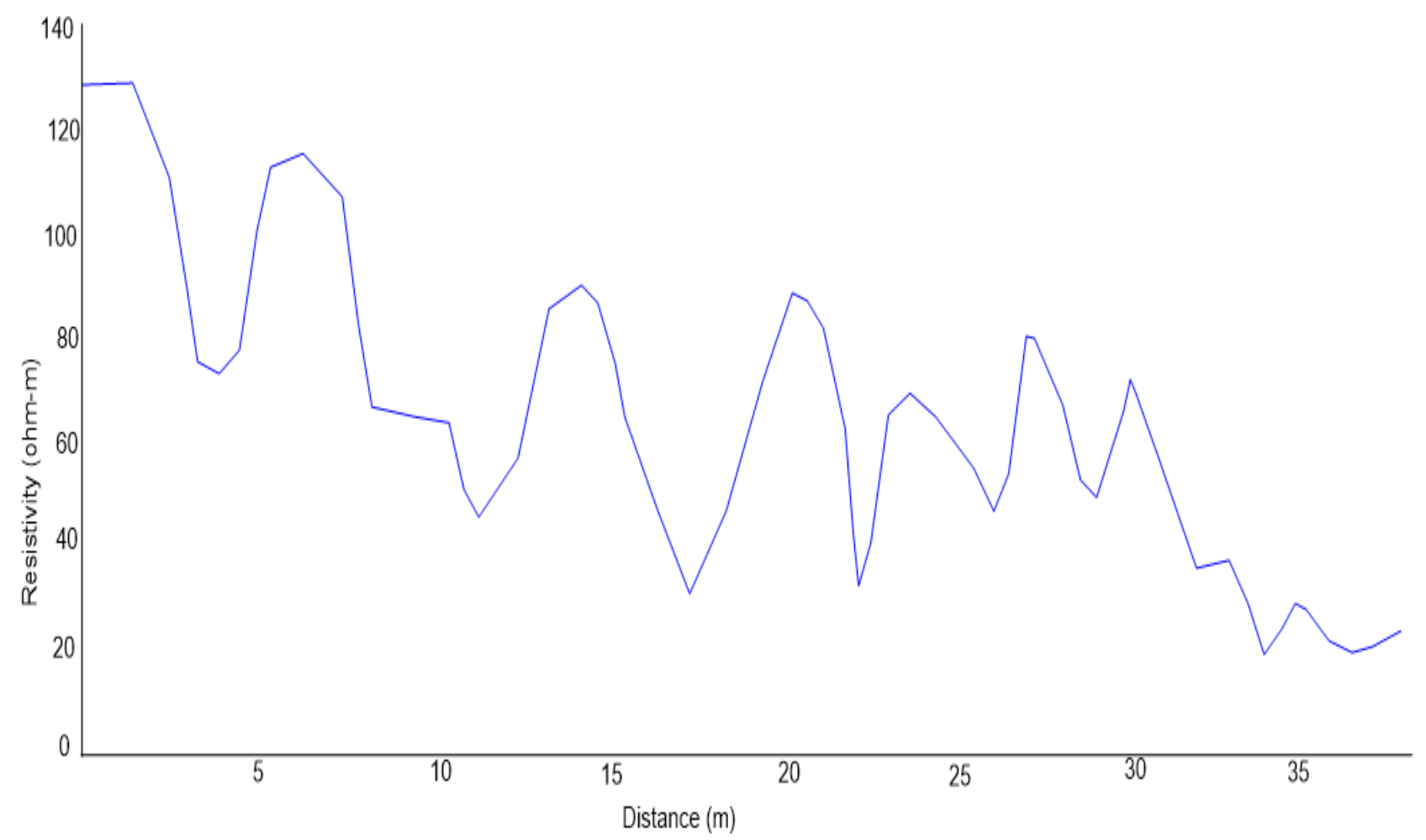

Fig. 6: Graph of Resistivity against Distance showing the Corrosivity of Profile 4 in the study area.

\section{GENERAL EVALUATION OF THE CORROSIVITY OF THE STUDY AREA}

The resistivity values of the study area on average are generally low with three out of the four profiles showing low resistivity values (Table 7). The profile with the highest average resistivity values was profile one which has an average resistivity value of $369.3847 \Omega \mathrm{m}$. This is because of the presence of sandy clay to clayey sand materials which do not readily retain much water within its pore spaces which act as electrolyte. This however cannot be said of Profiles two, three and four where their average resistivity values ranges from low $(42.5951 \Omega \mathrm{m})$ to intermediate $(94.7353 \Omega \mathrm{m})$ which may be due to the shallow nature of the chiefly clay materials in the subsurface of the profiles. Figure 7 shows that, the eastern part of the study area has low corrosivity $(\rho \geq 180 \Omega \mathrm{m})$ whiles the remaining part of the study area indicates high corrosivity $(\rho \leq 180 \Omega \mathrm{m})$. Over $90 \%$ of the 
study area has relatively low topsoil which is characterized by resistivity values with high tendency for corrosivity. However, the section around the eastern part of the study area was designated as practically noncorrosive. Hence, metallic pipes and other critical infrastructures buried around such areas may not be rapidly exposed to corrosion.

Table 7: Statistics of Profile Resistivity Values in the Study Area

\begin{tabular}{|c|c|c|c|c|}
\hline \multirow{2}{*}{ Profile } & \multirow{2}{*}{$\begin{array}{c}\text { Total VES } \\
\text { Points }\end{array}$} & \multicolumn{3}{|c|}{ Resistivity Values $(\Omega \mathrm{m})$} \\
\cline { 3 - 5 } & & Minimum & Maximum & Average \\
\hline 1 & 21 & 60.64 & 707.00 & 369.3847 \\
\hline 2 & 33 & 13.13 & 95.36 & 42.5951 \\
\hline 3 & 32 & 8.55 & 199.02 & 94.7353 \\
\hline 4 & 38 & 15.1 & 127.31 & 61.1123 \\
\hline
\end{tabular}

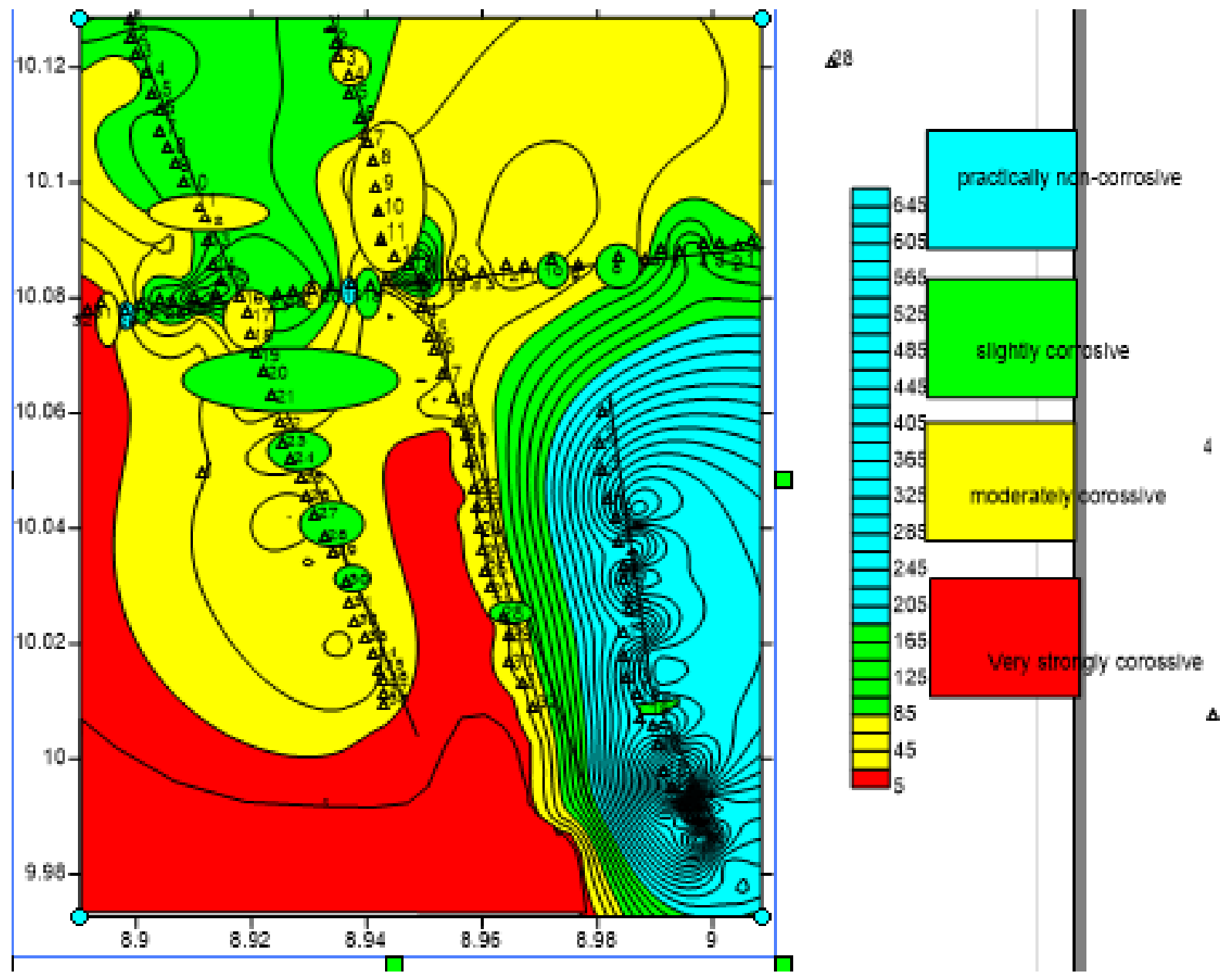

Fig. 7: Corrossivity map of the study area

\section{CONCLUSION}

It has been established that, there is a direct relationship between the earth resistance and soil corrosivity of the tested locations in the study area which invariably implies that the lower the soil resistivity, the higher will be the corrosivity value of the soil and vice versa. The locations within the tested sites with high, medium and low resistivity values have been carefully demarcated. It is therefore evident from the study that areas with sandy-clay and clayey-sand have the least corrosive potential while areas with clay materials seem to have the highest corrosivity index. 
It is recommended that materials such as Polyvinyl chloride (PVC) pipes and galvanized metals that are more resistant to corrosion should be used in areas with low resistivity values in order to prevent rapid rate of corrosion. Also, sulphate, chlorite and Soil pH tests of the study area need to be carried out to complement the resistivity study.

\section{REFRENCES}

[1] O. Agunloye, Soil aggressivity along Steel Pipeline Route at Ajaokuta, South-western Nigeria. Nigerian Journal of Mining and Geology, Vol. 21 (1 and 2), 1984, pp. 97-101.

[2] M.I. Alhazzaa, A Comparative Study of Soil Corrosivity of the University Campus. Final Research Report No. 45/426, King Saud University College Of Engineering Research Center, 2007, pp. 27.

[3] W.V. Baeckmann, and W. Schwenk, Handbook of Cathodic Protection: The Theory and Practice of Electrochemical Corrosion Protection Technique; Surrey Protucullin Press, 1975.

[4] O.G. Bayowa, and N.S. Olayiwola, Electrical Resistivity Investigation for Topsoil Thickness, Competence and Corrosivity. Department of Earth Science Ladoke Akintola University, 2015, pp. 53

[5] E.A.M. Idornigie, M.O. Olorunfemi, and A.A. Omitogun, The Electrical Resistivity Determination of Subsurface Layer, Subsoil Competence and Soil Corrosivity at Engineering Site Location in Akungba-Akoto, Southwestern Nigeria, 2006.

[6] P. Mccurry, Geology of Nigeria Sheet 21 (Zaria), MSc. Thesis, Ahmadu Bello University, 1970.

[7] A.O. Oyubu, Soil Resistivity and Soil pH Profile Investigation: A Case Study of Delta State University Faculty of Engineering Complex. International Journal of Scientific \& Engineering Research, Volume 6, Issue 10, 2015, pp. 22295518

[8] Y. Paillet, N. Cassagne and J.J. Brun, Monitoring the Forest Soil Properties with Electrical Resistivity. Biology and Fertility Soil, 46, 2010. pp. 451.

[9] L.O.A. Oyinkanola, J.A. Fajemiroye, B.O. Tijani,and D.A. Oke, Correlation between Soil Electrical Resisitivity and Metal Corrosion based on Soil Types for Structural Designs. Scientific Research Journal (SCIRJ), Volume IV, 2016. Pp. $2201-2796$ 